\title{
Selected Issues of E-Democracy and Political E-Participation
}

\author{
Wybrane problem e-demokracji \\ i partycypacji politycznej
}

\section{- Abstrakt •}

Rozwój technologii informacyjnych i rozwój społeczeństwa sieciowego poskutkował rozwinięciem się demokracji elektronicznej. Nie może ona być traktowana jako jedna z form istnienia demokracji, gdyż jest zjawiskiem jakościowo od demokracji odmiennym, podobnie jak społeczeństwo sieciowe nie jest wirtualnym ekwiwalentem społeczeństwa obywatelskiego. Wysunięto hipotezę, że rozwój technologii informatycznych być może polepsza w niektórych aspektach i skali stan demokracji, ale wyłącznie w przypadku gdy system jest realnie, a nie tylko deklaratywnie demokratyczny w sytuacji wyjściowej, niezależnie od postępu technologicznego. Jednym $\mathrm{z}$ elementów konstytuujących demokrację, w tym partycypację polityczną, jest świadomość obywatelska. Cyberspołeczeństwo, stanowiące antymodel społeczeństwa obywatelskiego (Castells) realizuje w sieci potrzeby dyktowane przez konsumeryzm i świadomość konsumenta, a nie ethos obywatelski i świadomości obywatela. Zatem ocena dynamiki rozwoju e-demokracji w poszczególnych państwach nie powinna być podstawą wniosków o kondycji istniejącej tam demokracji.

\section{- Abstract •}

The development of information technology and the development of a network society have encouraged a rise of e-democracy. It can not be regarded as a form of democracy because it is a phenomenon qualitatively different from democracy, similarly the network society is not the virtual equivalent of a civil society. It has been hypothesized that the development of information technology perhaps improves the state of democracy in some aspects and to some scale, but only if the system is real and not just declaratively democratic in the initial situation, regardless of technological progress. One of the elements that constitute democracy, including political participation, is a civic consciousness. On the web, the cyber-society constituting the anti model of civil society (Castells) implements the needs dictated by consumerism and consciousness of the consumer but not the ethos of civic and citizen awareness. Therefore, the rating of e-democracy dynamics in individual countries should not be the basis for conclusions about the condition of the existing democracy there. 
Słowa kluczowe: Internet, e-demokracja, partycypacja polityczna, społeczeństwo sieciowe, świadomość obywatelska
Keywords: Internet, e-democracy, political participation, network society, civic consciousness

The extremely dynamic development of media and information technology results in new phenomena in social and political spheres. They do not resemble previously known phenomena or situations with regard to possession and ways of functioning. To study these phenomena or situations, it is not only required for them to be formulated using adequate categories on a definitional level, but also to find new tools for examining the mechanism of their action. The informational model of democracy analysed by researchers as virtual, digital or electronic democracy, teledemocracy, cyber democracy and also cyber-society, network society, electronic society, etc., counts among the phenomena of this type (see: Snider, 1994; PercySmith, 1995; Loader, 1998; Moore, 1999). The definition of the Organisation for Economic Co-operation and Development, assumes that e-democracy takes place on three levels: informing, consulting, and active participation in political life. This type of democracy is considered to be a top-down action undertaken by local authorities and governments and, at the same time, a grassroots initiative undertaken in the network.

Electronic democracy is investigated as one of symptomatic aspects of existing and functioning of democracy today. Researchers regard electronic democracy as a form of direct democracy or technically improved version of representative democracy. Anyway, it is necessary to start the debate on a new type of democracy with emphasizing the fact that the development of information technology may improve some aspects and scale of the state of democracy, but only when the system is actually, not just declaratively democratic in the initial situation, regardless of technological advance. It is not the technology that creates democratic processes but the political will of the society. One should not deceive oneself that the dynamic development of new media, technological innovation, and also easier and easier access to any type of information could stop the global crisis of democracy. One factor that contributes to the crisis is the impairment of traditional political groups due to the fact that a part of power of competence was shifted to international institutions and the other part to local communities, which are not always able to reach their objectives efficiently. It results in an increasing skepticism towards politicians as well as participation in politics. Can new media and their potential overcome the scepticism to such an extent that active citizenship in the public sphere is increasing considerably? And if that is the case, can it be applied to making political decisions? 
Studying the electronic democracy by means of tools used in description and research of democratic processes can deliver interesting results only if one determines the awareness of network society (see: Castells, 2007). Following the idea of e-democracy and the way it works resulting from that awareness. Differences between society and network society have been repeatedly described (Hagen) by mass communication science. It is beyond doubt that they present two dissimilar types of community, different with respect to their composition, ability to create interlinks, density, the degree of centralization and inclusiveness, and also their way of communication. Assuming a thesis that the electronic democracy is an attempt to implement representative democracy, we are not focusing on the instrumentalization of the democratic process or communication channels through which people exchange their opinions on the web, but on the awareness demonstrated by the network society, including political elites.

\section{Democracy and Awareness of Citizenship - Interdependence of Coefficients of Incoming Crisis on a Global Scale}

Politics in all democratic countries has changed into postpolitics - a media spectacle, in which political dissidents do not concentrate on real social needs, problems, and current tasks but on mutual intrigues and private interests, which are not always convergent with public interest. Many politicians are not engaged in solving actual social and political problems, they do not pursue politics in the sense that M. Weber argues for (Weber, 1987), but they continually spare no efforts to neutralize social energy so that it will not concentrate on the analysis of their identities. They do not listen attentively to the opinion of the democratic nation in order to turn its will into suitable political decisions; instead, they exert top-down pressure in a direct or more often manipulative way. Politics in most contemporary states defining itself as democratic and liberal comes down to incompetent camouflage of hidden steering, forcing bounds, and arbitrary decision-making about social and political matters (see: Karwat, 2012). In these circumstances, one should doubt in accurately developed awareness of citizenship of both political elites and the remaining participants of the processes. They are very often democratic in name only. The awareness of individuals that make up civil society should release their civil activity and Popper's openness (see: Popper, 1993), and it should also favour the development of associations that are of horizontal character. Yet, modern democratic societies show a lack of inclination to political participa- 
tion and disappearance of horizontal associations, at the same time maintaining enormously well-developed but superficial horizontal communication, which is directed at particularistic objectives. One can draw a conclusion that the awareness of citizenship in these societies is poorly developed or it has disappeared. The development of the network and mass media in general does not raise the awareness of citizenship to a higher level but, on the contrary, it deepens the crisis. Civil ethos, which should be the foundation of democracy and its motive force, exists first of all as theoretical category, important for researchers engaged in theory of politics and political thought. Modern democratic societies have become more and more dependent on information technology and they are even fascinated with the possibilities made by it as far as communication is concerned. This way they are changing into network societies and, at the same time, information societies - focused on improving the use of information techniques and creating the communication structure which serves this purpose. Their main objective is to gain the most accurate information available as quickly as possible, which is the condition of competitiveness in the industry and services in postindustrial states (Negroponte, 1997; de Kerckhove, 2001; Wieczorek, 2007). If the awareness of citizenship in democratic societies had been low before the attempts to fulfill tasks typical of democratic societies took place, what is the awareness of citizenship in cyber-society, which is a qualitatively different formation but it is genetically connected with the society from before the development of the network? No democracy - either in the network and owing to it, or outside the network - cannot realize itself without the awareness of citizenship. Therefore, this question seems to be fundamental when it aims at evaluating benefits from the use of the Internet in the democratic processes.

\section{Cyber-Society - a New Dimension or Anti-Model of the Civil Society?}

In Castells's opinion, virtual communities are not real, physical communities and as such they are not subject to the same patterns of communication and interaction as physical communities. They cannot imitate other life forms existing outside the network. In this communities, there is no attachment to one's own territory, culture, and its specific cultural codes, which was typical of the societies from before the web development. Cyber-society is marked by the blurring of social identity, a-historicism, and a lack of connection with geographically specific place, which results in disappearance of social institutions and replacing them with the 
idea of collective intelligence. We deal with departure from formalism and selfcontrollability. The identity of the Internet user is not determined in the context of their connection with a specific physically existing society, but in the context of their affiliation to "managerial information economy" of a global character (see: Kazanowski). The access to information is important, but willingness and ability to use information is even more important. The network society manages information, but in what way? In what way does it use information? Does the Internet give unlimited possibilities to manipulate political information or does it rather strengthen the possibilities of voter's defence against mass media manipulation? (Castells, 2003). The issues of selection of information by a sender and a receiver and also susceptibility to manipulative work remain within the consideration of the awareness of citizenship shown by the network users. It becomes important to interpret correctly the intention followed by those who place substantially and temporarily defined information on the Internet, and to examine the receiver's reaction to such information.

Cyber-society described by Castells is an anti-model of the democratic, civil and open society. In the context of Castells' vision of the functioning of the Internet and the network society, it is impossible to mention citizen initiatives in the network and owing to it. However, those who conduct research on the Internet think that the network creates conditions for the emergence of professionally organized, leading to real effects citizen initiatives inspired by principles coming from consolidated democracies (Dorenda-Zaborowicz, 2013). In opposition to Castells, it is assumed that cyber-societies are not a separate and qualitatively different phenomenon from non-virtual societies but make up their sum functioning in the circumstances of extensive possibilities. These researchers assume that the tools employed by the civil society and known outside the network are also used in the network, and their organisers' and participants' motivations have not changed. The only thing that has altered is the range of influence and the repertoire of methods of aiming at intended objectives. It is difficult to question accuracy of Castells' defining the cyber-society as amorphous and not assigned to any territory. However, according to the followers of the Internet vision as a medium and platform for democratic actions undertaken by citizens (in a classical and exemplary sense of the word), the global nature of the cyber-society by no means does not limit its actions in favour of maintaining or modification of state or/and national system. Even though the network society is morphologically conditioned by wider operating range than it is determined by the state border, besides the undertaken objectives are usually short-term and they are stable in a little degree, local affairs quite often appear in its range of interest. 
Samuel Barber, although in a different way than Castells, believes that there are the same rules of public life both in cyberspace and outside it; in the 1990s, he finally shared Castells's doubts concerning the cyber-society's predisposition to democratic actions. He questioned the thesis that computerization and digitization of democratic actions could increase citizens' interest in public affairs improving simultaneously the state of political participation in modern democratic states. In the middle of the 1980s, when the use of the Internet was not as widespread, Barber expressed his optimism about the usefulness of this tool for the improvement of the quality of democracy. His optimism resulted from the assumption that the cyber-society as one of the "embodiments" of the democratic society, not a different phenomenon both in respect to its quality and functioning, can develop its public activity through the network. At the same time, he advanced a thesis that cyber-society is some kind of civil society and as such it potentially has more possibilities to undertake civil activities than the society that does not use the Internet. However, this potential - as Barber stated - could be activated only at the time when a real transfer of decisiveness from the highest to lower levels of administration: local authorities and local communities comes into being. He rightly remarked that people think being active in the public sphere makes sense only when their arrangements are likely to reach irrespective of the ruling elites' standpoint or owing to these elites. In the last case, political elites really take public action into consideration creating legal basis for their implementation. If this democratic mechanism functions well, the Internet - as Barber wrote in the 1980s - could become a means for improving democratic processes allowing to present and confront the standpoints of all interested parties in a short time, formulate postulates concerning matters important for particular communities, present them to political elites and immediately get information about decisions on these matters. Such degree of democracy consolidation in particular states and serious commitment of the cyber-society's members in public affairs contribute to the possibility that the Internet could have fulfilled the hopes placed on it. Ten years later, Barber recognized their futility in the face of political realities neither the establishment of particular states is prone to turn a lot of postulates propounded by citizens into adequate political decisions, nor - in connection with this - the citizens look upon the Internet as a politically efficient platform for promoting their own interests (Barber, 2003; Barber, 1998; see: Porębski, 2001). Such perversion of the democratic system at the bottom is important but not the only one reason for low efficiency of the e-democracy. 


\section{Citizen Initiatives on the Internet. The Potential Used Insufficiently}

Researchers studying the citizen initiatives on the Internet (Vegh, 2003) discern several kinds of citizen initiatives, which altogether express commitment of at least part of the network users with their specific, locally important matters. The first dimension and axis of division are "old" and "new" forms of collective actions. The first of them belong to a repertoire of "old" types of activity, which are only improved by the network. The second kind of them are virtual activities taking place entirely in the network. They are based on the Internet as a whole, they do not exist without functioning in the network (Van Laer, Van Aelst, 2010). Research conducted by Marta Dorenda-Zaborowicz (Dorenda-Zaborowicz, 2013) showed that to the "old", known before the period of the Internet development, traditional forms of support or involvement in the citizen initiatives belong:

- collecting donations from sponsors (through the Internet payment sites or click-to-give mechanism), at the same time product/make endorsement takes place, which in this case is this particular action;

- demonstrations - the network can serve as a channel of coordination and mobilization of participants who take part in street demonstrations. It mainly applies to the distribution of information about purposes and reasons of the action and also the logistics of a prepared action. The information about transnational and foreign demonstrations could also be placed on the websites;

- sit-in - a form of a direct action consisting in occupation of a territory in order to express protest or support for a case.

The civil actions taking place entirely in the network include:

- on-line petitions. They can be spread by social networking services. However, each user, even without the agency of such services, can create a profile regarding a specific issue where he expresses his/her attitude towards it and then spread it among other Internet users;

- spammers' attacks consist in sending a big number of e-mails in a short time to people responsible for solving of the issue being the subject of the action. As a result, mailboxes and servers are blocked. Moreover, it reveals the strength of support for a given issue (Meikle, 2002). Another way of action /protest - the so-called "hacktivism" - is opening a specific website with such a frequency that the server it is put on cannot serve the number of questions and it finally crashes (du Vall, 2010);

- the websites of alternative media. The political and social matters published 
and spread on these websites present a viewpoint different from this expressed in mass media.

Although this classification does not grant a place for such basic forms of civil activity as a debate (see: Porębski, 2013; Mider, 2008) and e-voting, it points at great possibilities of the Internet as far as activation of civil actions is concerned. However, the quantitative research conducted by the Polish researcher of political cyber-activity Dorenda-Zaborowicz leads to the conclusion that these possibilities are partially used by the Polish users of the network, most often by the agency of YouTube and Facebook services. The reason for this state of affairs is the degree commercialization of all aspects of life. It does not favour either the civil activity or even thinking over it. The Internet functions according to market rules and it subjected the users' thinking and activity to these rules a long ago. Both outside and in the network citizens are treated and function in accordance with a consumer's, not a citizen's logic. A consumer's awareness and a citizen's awareness are two different categories occupying the opposite poles. Discussion lists and citizen discussion forums have not disappeared from the Internet but they have been shifting to peripheries for a long time. "Public debates" about local affairs take place on the Internet forums but what is their range and level? Information about reality or local events are not a starting point for an activity which could be legitimately named a public debate. A debate is "a serious and long discussion on an important subject" (Stownik jezyka polskiego). The quality of discussions conducted on the Internet is bad, which results i.a. from their anonymity and the possibility of making or breaking contact any moment not taking the responsibility for the content of their statements. The lack of censorship is both its advantage an drawback. The cyber-society does not create the network of social engagement, it also does not establish norms, which facilitate coordination and co-operation. The principle of mutuality, which is the basis for social trust, does not work here. Putting it into Robert Putnam's words ${ }^{1}$, the social capital of the cyber -society seems to be very low (see: Putnam, 1993). The groups coming into being on the Internet are unstable and amorphous in character. They have no one real place. Their meetings and talks in the network are of accidental, superficial character, they are not directed towards common and responsible performing of the tasks, including political tasks. Communication on the Internet is not subjected to any moral regulation, it assumes any form, sincerity is not always considered useful or

${ }^{1}$ R. Putnam studied the dependence between a very low level of social capital in American society, and withdrawing of its citizens into a private life. Americans to a lesser and lesser degree join social and political life, yet technological progress is continuouslly advancing in their country. 
desirable. Many people think that for that reason it has the advantage over direct communication, outside the network. However, the lack of any setbacks or social and moral norms causes that opinions expressed on the Internet are often unconsidered, purposefully falsified, and excessively radical. An individual is not treated as a subject but more and more often as a thing, besides he/she is alienated, which is deadly for democracy.

\section{References:}

Barber, B.R. (1998). A Passion For Democracy. American Essays. Princeton: Princeton University Press.

Barber, B.R. (2003). Strong Democracy Participatory Politics for a New Age. Berkeley-Los Angeles-London: University California Press.

Castells, M. (2003). Galaktyka Internetu. Refleksjenas Internetem, biznesemispołeczeństwem. Poznań: Dom Wydawniczy Rebis.

Castells, M. (2007). Społeczeństwo sieci. Warszawa: PWN.

de Kerckhove, D. (2001). Inteligencja otwarta. Narodziny społeczeństwa sieciowego. Warszawa: Mikom.

Dorenda-Zaborowicz, M. (2013). Powstawanie, funkcjonowanie oraz oddziaływanie inicjatyw obywatelskich w internecie. Athenaeum. Polskie Studia Politologiczne, Vol. 37, $58-74$.

Du Vall, M. (2010). Electronic civil disobiedience (ECD) jako jedna z form obywatelskiego nieposłuszeństwa. Państwo i Społeczeństwo, no 2, 123-133.

Hagen, M. A Typology of Electronic Democracy. Derived from: http://www.unigiessen.de/ $\mathrm{fbo3/vinci/labore/netz/hag \_ en.htm.}$

Karwat, M. (2012). O karykaturze polityki. Warszawa: Muza SA.

Kaznowski, D. Archiwum kategorii "Społeczeństwo sieci”. Dwie logiki przestrzenne społeczeństwa, Castells - komentarz. Derived from: http://networkeddigital.com/category/manuel-castells/spoleczenstwo-sieci/.

Loader, B. (eds.). (1998). Cyberspace Divide. Equality, Agency and Policy in the Information Society. New York: Routledge.

Meikle, G. (2002). Future Active: Media Activism and the Internet. New York-London: Routledge.

Mider, D. (2008). Partycypacja polityczna w internecie. Warszawa: Elipsa.

Moore, R. (1999). Democracy and Cyberspace. In: W. Hague, B. Loader (eds.), Digital Democracy. Discourse and Decision Making in The Information Age (p. 39-60). New York: Routledge.

Negroponte, N. (1997). Cyfrowe życie. Warszawa: Książka i Wiedza.

Percy-Smith, J. (1995). Digital Democracy. Information and Communication Technologies in Local Politics. London: Commission for Local Democracy.

Popper, K.R. (1993). Społeczeństwo otwarte i jego wrogowie. Warszawa: PWN. 
Porębski, L. (2001). Elektroniczne oblicze polityki. Demokracja, państwo, instytucje polityczne w okresie rewolucji informacyjnej. Kraków: Wydawnictwo AGH.

Porębski, L. (2013). Więcej, szybciej, łatwiej. O radościach i smutkach związanych z elektroniczną demokracją. In: R. Marczewska-Rytko (eds.), Demokracja elektroniczna. Kontrowersje i dylematy (p. 13-31). Lublin: Wydawnictwo UMCS.

Putnam, R. (1993). The Prosperous Community. Social Capital and Public Life. American Prospect, Vol. 13, 35-42.

Stownik języka polskiego. Derived from: http://sjp.pwn.pl/haslo.php?id=2554300.

Snider, J. (1994). Democracy On-line. Tomorrow's Electronic Electorate. The Futurist, Vol. 28 (5), 15-19.

Van Laer, J., Van Aelst, P. (2010). Cyber-protest and civil action repertoires in social movements. In: Y. Jewkes, M. Yar (eds.), Handbook on Internet Crime (p. 230-253). Devon: Willan Publishing.

Vegh, S. (2003). Classifying Forms of Online Activism: The Case of Cyberprotests against the World Bank. In: M. McCaughey, M.D. Ayers (eds.), Cyberactivism. Online Activism in Theory and Practice (p. 71-95). New York-London: Routledge.

Weber, M. (1997). Polityka jako zawód i powołanie. Warszawa: Znak.

Wieczorek, M. (2007). Internet a społeczeństwo otwarte. Środkowoeuropejskie Studia Polityczne, no 2, 133-143. 